\title{
Mexican Redrump Tarantula, Brachypelma vagans (Ausserer) (Arachnida: Araneae: Theraphosidae) ${ }^{1}$
}

\section{G. B. Edwards and K. L. Hibbard² \\ Introduction}

In early August 1996, a large black spider with red hairs on its abdomen was collected by citrus grove workers in St. Lucie County, Florida, west of Ft. Pierce. The workers gave the spider to a citrus survey crew, who brought it back to Gainesville. The first author examined the specimen (which was only half grown) and tentatively identified it as Brachypelma vagans (Ausserer), a species known to be commonly imported by the pet trade under assorted common names (Central American, Guatemalan, Honduran, or Mexican black velvet tarantulas). The accepted common name is Mexican redrump tarantula (Breene 1995).

About a week later, a female and several young spiders were unearthed by grove workers in the same area. Subsequently, several survey expeditions led by the second author captured or destroyed about 100 specimens of all ages from small spiderlings to adult females and males. One of these males was sent to Rick C. West, a tarantula expert and research associate of the Royal British Columbia Museum, for identification. Mr. West confirmed that this species was B. vagans (personal communication 1996). He also noted that the species had been commonly imported into Miami since the early 1970s.

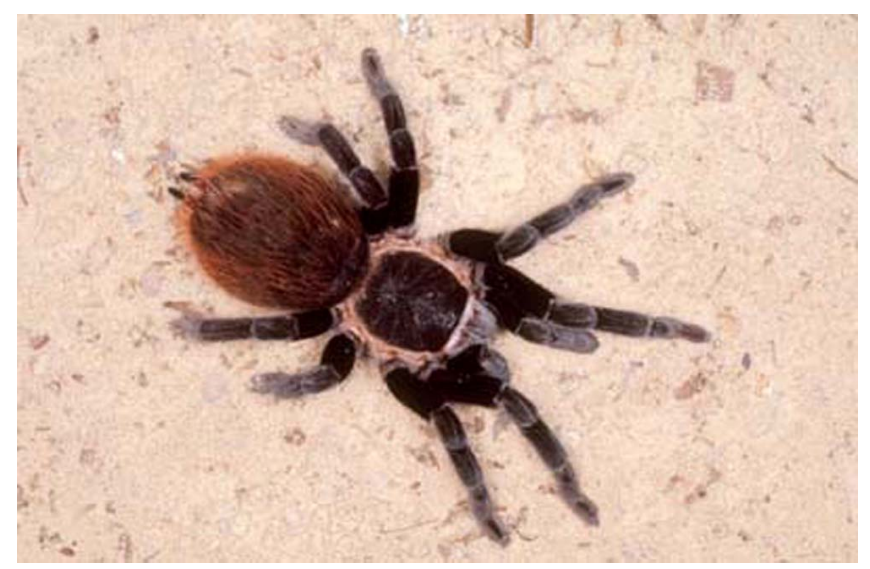

Figure 1. Female Mexican redrump tarantula, Brachypelma vagans. Credits: Jeffrey Lotz, Division of Plant Industry

\section{Distribution}

Mexican redrumps were reported from Belize, El Salvador, Guatemala, Honduras and Mexico (Baxter 1993; Smith 1986), but were omitted as a component of the Costa Rican fauna (Valerio 1980).

\footnotetext{
1. This document is EENY-287, originally published as DPI Entomology Circular 394, one of a series of Featured Creatures from the Entomology and Nematology Department, Florida Cooperative Extension Service, Institute of Food and Agricultural Sciences, University of Florida. Published: March 2003. This document is also available on Featured Creatures Website at http://creatures.ifas.ufl.edu. Please visit the EDIS Website at http://edis.ifas.ufl.edu. Additional information on these organisms, including many color photographs, is available at the Entomology and Nematology Department website at http://entnemdept.ifas.ufl.edu/.

2. G. B. Edwards and K. L. Hibbard, Division of Plant Industry, Florida Department of Agriculture and Consumer Services, Gainesville, FL.
} 
It is now known to occur naturally from Veracruz and the Yucatan Peninsula south along the Gulf coast to northeastern Costa Rica (R.C. West, personal communication 1996).

In Florida, a population was found in a 40 -acre citrus grove bordered by irrigation canals on the south and west. The tarantula population initially seemed to be restricted to about one acre in the southwest corner of the grove. Concurrent reports of specimens from the northeast corner of the grove could not be substantiated. Subsequent surveys have found them in burrows along about one half mile of the east bank of the irrigation canal bordering the west side of the grove, as well as a lesser eastern extension along the canal bordering the southern edge of the grove.

Wandering males have been found as far as 0.9 miles from the main population site. Later reports from nearby sites have not been verified with specimens, even though extensive surveys have been conducted in the area (to 1.0 mile east and west, 2.5 miles north, 4.0 miles south).

\section{Biology}

Like most tarantulas, the biology of $B$. vagans is poorly known (Carter 1997). Adult females are 5.0$7.5 \mathrm{~cm}$ in body length, with a leg span up to $13.5 \mathrm{~cm}$. Adult males are slightly shorter with a much smaller abdomen. The spiders are entirely black except for the long red to reddish-brown hairs on the dorsum of the abdomen; females also have reddish-brown hairs on legs III and IV (Baxter 1993). It is a fossorial species (i.e., it digs burrows); adult burrows are 4-5 $\mathrm{cm}$ in diameter and about $45 \mathrm{~cm}$ deep.

Mexican redrumps are nocturnal predators, feeding on ground-dwelling arthropods and possibly on small vertebrates (see Marshall 1996). The enemies of adult tarantulas in Florida likely consist primarily of small predatory mammals, whereas the young tarantulas also would be vulnerable to other arthropod predators, particularly other large terrestrial spiders, as well as frogs and toads. Like most other New World tarantulas, B. vagans defends itself against vertebrate predators with special urticating hairs on its abdomen. If these hairs get on the skin, they itch like bits of fiberglass, but if they get into mucus membranes and especially the eyes, much discomfort or injury could ensue. This species has not been reported to possess a bite serious to people (Breene et al. 1996).

In Florida, males and females with young seemed to be most prevalent in the autumn, although specimens of all sizes can be found year-round. This is unquestionably due to the fact that individuals of this species live for many years. Individuals of some species in this genus are thought to live at least 25 years in the wild, and longer in captivity. Although some congeners are thought to take five to seven years to mature, B. vagans can be raised to adult in captivity in two to three years (Baxter 1993).

Females make large silken eggsacs $4-5 \mathrm{~cm}$ in diameter, and the spiderlings stay with the mother for up to several weeks before they disperse. Four captured females made eggsacs in the laboratory, averaging about 100 young per eggsac, although as many as 300 have been reported for this species (Moore 1994), with unpublished reports as high as 800 (Y. Evanou, personal communication 1998).

The establishment of this species in Florida is not surprising. Parts of the Yucatan Peninsula in Mexico are somewhat similar in soil type, vegetation type, and climate to areas of central Florida. We will probably never know exactly how this species came to be introduced into this particular area. One early hypothesis was that a single gravid female escaped or was released. This was based on the fact that one of the earliest captured specimens molted into a deformed male in the laboratory, and it was suspected that the deformity was caused by inbreeding. Since then, many more perfectly normal specimens have been captured, and it is now thought that the specimen was deformed because it was injured during capture.

It is likely that this population has been in this location for over ten years, indirectly supporting the allegation that several specimens were released by a commercial pet importer or breeder at this locality during the 1970s. A reliable sighting of an adult male in 1989 by a pair of herpetologists looking for reptiles along an adjacent paved road was reported in October 1996, after the discovery of this tarantula in Florida was publicized. Given the known maturation time of 
this species, this would mean that a population has been in the area since at least 1986.

Why they have not become more widespread is not understood, but tarantulas are known to be habitat restricted in the wild and they do not disperse very far (Gertsch 1979). The area where they are established seems to provide the tarantulas with an abundance of food, water, and proper soil to burrow in, so there does not appear to be a need for them to widely disperse. However, the potential for the species to become widespread in Florida given enough time cannot be discounted. The environment of Florida has been plagued by the destructive establishment of exotic organisms for many years (Thomas 1995).

Although the ultimate effect of a naturalized tarantula in Florida cannot at this time be accurately predicted, it would be irresponsible to assume that they will not have a deleterious effect on native wildlife. With this in mind, eradication has been attempted, so far unsuccessfully. If these efforts do not succeed, we still will be able to track the spread of this species and monitor its impact on the environment.

\section{Selected References}

Baxter RN. 1993. Keeping and Breeding Tarantulas. Chudleigh Publishing, Essex, England. 89 pp.

Breene RG. 1995. Common Names of Arachnids 1995. American Tarantula Society, Publisher. South Padre Island, Texas. 94 pp.

Breene RG, Dean DA, Cokendolpher JC, Reger BH. 1996. Tarantulas of Texas: Their medical importance, and world-wide bibliography to the Theraphosidae (Araneae). American Tarantula Society, Publisher. South Padre Island, Texas. 73 pp.

Carter N. 1997. Who's on CITES and why?

Forum of the American Tarantula Society 6: 172-173.

Gertsch WJ. 1979. American Spiders. 2nd ed. Van Nostrand Reinhold Co., New York. 274 pp.

Marshall SD. 1996. Old dog learns new trick. Forum of the American Tarantula Society 5: 114-116.
Moore BH. 1994. Red rumped cannibals. Forum of the American Tarantula Society 3: 14-15.

Smith A. 1986. The Tarantula: Classification and Identification Guide. Fitzgerald Publishing, London. 178 pp.

Thomas MC. 1995. Invertebrate pets and the Florida Department of Agriculture \& Consumer Services. Florida Entomologist 78: 39-44.

Valerio CE. 1980. Arañas terafosidas de Costa Rica (Araneae, Theraphosidae). I. Sericopelma y Brachypelma. Brenesia 18: 259-288. 